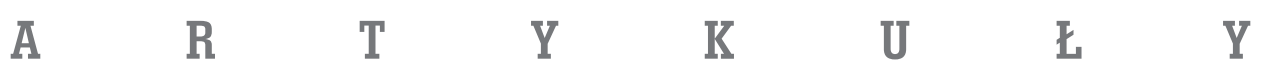

Tomasz Jacek Lis

Uniwersytet Mikołaja Kopernika w Toruniu

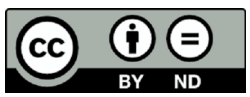

\title{
Osadnictwo Rusinów w Bośni i Hercegowinie na przełomie XIX i XX wieku
}

Zarys treści: Artykuł prezentuje wyniki badań nad kolonizacją Rusinów w Bośni i Hercegowinie w latach 1878-1914, genezę zjawiska osadnictwa na tych terenach, a także ich problemy związane z emigracją. Głównymi wątkami są ich procesy akulturacji, nie tylko w kontakcie z autochtonami, ale także z Polakami, którzy również osiedlali się licznie w okolicach Banja Luki. Ponadto poświęciłem dużo miejsca stosunkowi greckokatolickich władz kościelnych wobec problemu wychodźstwa unitów. Wielu Rusinów, w pierwszych latach po przybyciu do Bośni i Hercegowiny, z powodu braku własnych duchownych decydowało się przejść na prawosławie. Sytuacji tej starały się przeciwdziałać miejscowe władze kościelne i świeckie w porozumieniu $\mathrm{z}$ abp. Andrzejem Szeptyckim.

Outline of content: This article presents the results of a study on the immigration of Ruthenians to Bosnia and Herzegovina in the period 1878-1914, as well as the source of settlement movements in this area and the issues associated with emigration. The study concentrates mainly on the processes of their acculturation in contact not only with locals, but also with Poles, who also settled in large numbers in the area of Banja Luka. Much space is also devoted to the attitude of the Greek Catholic Church authorities towards the issues pertaining to the emigration of their adherents. Due to lack of their own clergy, many Ruthenians converted to Orthodoxy in the first years after arriving in Bosnia and Herzegovina. Both local religious and secular authorities attempted to counteract this situation in consultation with Archbishop Andrey Sheptytsky.

Słowa kluczowe: Bośnia i Hercegowina, Austro-Węgry, Polonia na Bałkanach

Keywords: Bosnia and Herzegovina, Austria-Hungary, Poland and the Balkan

Artykuł w sposób skrótowy prezentuje subiektywny wybór najważniejszych faktów z historii osadnictwa rusińskiego w Bośni i Hercegowinie na przełomie XIX i XX wieku. Cezurą początkową są lata 90., końcową zaś - 1918 rok. Zdecydowałem się zakończyć tą datą, gdyż to wówczas Bośnia i Hercegowina znalazła się w zupełnie innej politycznej sytuacji, która wymaga osobnego studium. Artykuł jest przyczyn- 
kiem, który ma na celu zasygnalizowanie pewnych problemów i zachęcenie badaczy do zajęcia się tym zagadnieniem. W polskiej historiografii o kolonistach rusińskich wspomina się wyłącznie przy okazji ich konfliktów z Polakami. Nie spotkałem się natomiast $\mathrm{z}$ jakimkolwiek opracowaniem, które swoją uwagę poświęciłoby wyłącznie sprawie ich emigracji na Bałkany.

Bośnia i Hercegowina, na mocy umów zawartych na Kongresie Berlińskim (1878 r.), znalazła się w austro-węgierskiej strefie wpływów. Wcześniej przez ponad 400 lat znajdowała się w strefie wpływów Imperium Osmańskiego. W krótkim czasie po tym wydarzeniu liczni emigranci z Niemiec, Włoch, Węgier, a także Czech zaczęli napływać do tego bałkańskiego kraju w poszukiwaniu taniej i żyznej ziemi pod uprawę. Po jakimś czasie pojawili się także osadnicy z ubogiej Galicji. Najpierw pojedynczo, a następnie większymi grupami emigrowali za chlebem na Półwysep Bałkański.

Historia kolonizacji rusińskiej w Bośni i Hercegowinie sięga właśnie 1893 r., kiedy to Rząd Krajowy w Sarajewie zdecydował się w ramach kolonizacji rządowej osiedlić rolników z Galicji. Wówczas w okolice Banja Luki przybyli pierwsi rusińscy koloniści - łącznie 72 rodziny, które dały początek miejscowości Kličkovo Brdo ${ }^{1}$. Warto na chwilę zatrzymać się przy zagadnieniu, które porusza problem rodzin chłopskich, głównie z Galicji, ale także z Bukowiny, Wołynia i innych południowo-wschodnich terenów wchodzących w skład Monarchii Austro-Węgierskiej, opuszczających rodzinne tereny i udających się na tułaczkę po Bałkanach².

$\mathrm{Na}$ terenach byłej Rzeczypospolitej, przynależących do Austro-Węgier od czasów Kongresu Berlińskiego i likwidacji Wolnego Miasta Krakowa w 1846 r., istniała ogromna bieda, którą najbardziej odczuwano na wsi. Panowało przeludnienie powodujące jeszcze większą pauperyzację chłopstwa, w tym także unickiego. Słaby poziom wiedzy rolniczej, brak sprzętu, a przede wszystkim ziemi, to tylko niektóre z powodów takiego stanu rzeczy. Przedmiotem artykułu nie jest szczegółowa analiza tego problemu, dlatego w załączniku odsyłam do podstawowej literatury dotyczącej przyczyn wychodźstwa chłopskiego z Galicji³.

W II połowie XIX w. zwiększył się wyraźnie ruch migracyjny w porównaniu do pierwszego pięćdziesięciolecia. Popularnymi kierunkami emigracji dla ludności z wyżej wymienionych terenów były przede wszystkim zamorskie kraje w Ameryce Północnej i Południowej, takie jak USA czy Brazylia. Wiele osób obawiało się jednak

1 A. Busuladžić, Pojava grkokatoličkog stanovništva u Bosni i Hercegovini, „Izvorni Znanstveni Članak" 1/2003, t. 35, s. 175.

2 W dalszej części pracy będę posługiwał się terminem Galicja na określenie miejsca, z którego dotarli koloniści, gdyż większość z przybyłych rekrutowała się właśnie z tych terenów.

3 Temat ten był wielokrotnie dyskutowany, dlatego przywołam tylko wybrane, moim zdaniem najważniejsze, pozycje bibliograficzne: por. S. Szczepanowski, Nędza Galicyjska w cyfrach i program energicznego rozwoju gospodarstwa krajowego, Lwów 1888; M. Kozaczka, Wsychodźstwo zarobkowe $z$ Galicji do Ameryki (do 1914 r.), [w:] Chłopi. Naród. Kultura. Chłopi a państwo, red. W. Bonusiak, Rzeszów 1997, s. 189-199; J. Mazanek, Kraj a emigracja galicyjska, Warszawa 2006; M. Kula, Polonia brazylijska, Warszawa 1981; W. Isaac, F. Znaniecki, Chłop polski w Europie i Ameryce, Warszawa 1976; E. Ciuruś, Z. Dobosiewicz, W. Rómmel, Polonia w Ameryce Łacińskiej, Lublin 1977. 
tak dalekiej podróży. Dla niepiśmiennych chłopów wyjazd do Bośni, znajdującej się we władaniu dobrze znanego cesarza Franciszka Józefa, wydawał się zdecydowanie mniej ryzykownym przedsięwzięciem niż zamorska wyprawa. Nie mając podstawowej wiedzy na temat miejsca docelowego, decydowali się opuścić rodzinne strony i spróbować swoich sił w obcym kraju. Początkowo wiedzę o bezkresnych hektarach leżących odłogiem w Bośni i Hercegowinie czerpali od żołnierzy, którzy w ramach kontyngentu wojskowego najpierw walczyli, a następnie stacjonowali w Bośni. Krzysztof Baczkowski twierdzi, iż w okresie przynależności do Austro-Węgier przez ten bałkański kraj przeszło ok. 12 tys. żołnierzy z Galicji, w większości szeregowych, czyli chłopskich synów ${ }^{4}$, którzy po powrocie w rodzinne strony zachęcali krewnych do wyjazdów. Trudno nie docenić ich roli w tym procesie. Uważam wręcz, że zanim doszło do upaństwowienia procesu kolonizacyjnego, to właśnie żołnierskie opowieści były główną zachętą do migracji na Bałkany5. Jeśli udało się wyjechać w okresie od 1894 do 1905, to istniała duża szansa na otrzymanie działki od władz miejscowych. Przez ten czas Rusini wraz z Polakami dostali łącznie 14352 ha gruntów ${ }^{6}$. Jednak po 1910 r., na skutek protestów miejscowej ludności, zaniechano rządowego planu rozdawnictwa ziemi. Nie zniechęciło to jednak chłopów do emigracji, przeciwnie - nadal przyjeżdżali w celu osiedlenia się. Tym samym w 1910 r. liczba grekokatolików wzrosła kilkudziesięciokrotnie i przekroczyła 8 tys. osób, podczas gdy w 1895 r. odnotowano zaledwie 163 osoby tego wyznania ${ }^{7}$. Nie byli to jedynie Rusini, którzy decydowali się na emigrację. Część osób musiała wrócić, ponieważ nie spełnili warunków stawianych przez Rząd Krajowy ${ }^{8}$.

Ludność, która chciała wyjechać do Bośni i Hercegowiny, korzystała najczęściej z usług licznych pośredników. Ich zadaniem było zorganizować bezpieczny transport kolonistom, a także uregulować kwestie prawne związane z objęciem przezeń gruntu pod uprawę roli ${ }^{9}$. O zapotrzebowaniu na tego typu usługi najlepiej świadczy ich rozwój w pierwszych latach po wejściu Bośni i Hercegowiny w strefę wpływów Austro-Węgier. Jednak brak prawnych regulacji wywoływał poczucie chaosu, gdyż firmy pośredniczące w osiedlaniu niezagospodarowanych terenów nie zawsze wywiązywały się ze swoich obowiązków. Mimo że kwestia kolonizacji była od początku dyskutowana w kręgach najwyższych władz w Sarajewie ${ }^{10}$, sytuacja uległa zmianie

4 K. Baczkowski, Żołnierze narodowości polskiej w podboju i okupacji Bośni i Hercegowiny przez Austro-Wegry (1878-1914), „Zeszyty Naukowe Uniwersytetu Jagiellońskiego. Prace Historyczne 2000”, z. 127, s. 107-119.

5 Trudno ustalić jakiekolwiek statystyki na ten temat, niemniej spotkałem się w trakcie kwerendy archiwalnej z pismami żołnierzy, którzy prosili o nadanie im działki w Bośni po odbytej służbie.

6 Archiwum Bośni i Hercegowiny, Zajedničko Visoko Stanovništvo [dalej: ABH, ZVS] 1905, 134 218/3, s. 9 .

7 Dane podane na podstawie: Glavni rezultati popisa žiteljstva u Bosni i Hercegovini od aprila 1895, Sarajevo 1896, a także: Rezultati popisa žiteljstva u Bosni i Hercegovini u 1910, Sarajevo 1912.

8 ABH, ZVS, 1903, 4 45/359, s. 3.

9 A. Kasumanović, Modaliteti eksterne kolonizacije u Bosni 1890-1914: Case Study za njemačke erarne kolonije, „Prilozi” 38/2009, s. 83-84.

10 Ibidem, s. 85. 
dopiero po dojściu do władzy Benjamina Kállaya, węgierskiego administratora Bośni i Hercegowiny w latach 1882-1903. Zdolny działacz postanowił wykorzystać zyski płynące z kolonizacji dla własnej polityki narodowej, którą prowadził ${ }^{11}$. Uregulował on przede wszystkim kwestie związane z nadawaniem działek, ich wielkością, a także obowiązkami i przywilejami „kolonisty rządowego”. Każdy osadnik (w tym także Rusin) otrzymywał działkę o wielkości 10-12 ha, którą dzierżawił przez 10 lat. Po tym okresie miała mu ona zostać oddana jako jego własność. Jeśli oddany grunt był zalesiony, to przesiedleniec zobowiązywał się do jego wykarczowania i użytkowania przez okres dzierżawy ${ }^{12}$. Wydaje się, że był to najtrudniejszy moment dla nowo przybyłego kolonisty. Pozbawiony specjalistycznego sprzętu, a także pomocy ze strony sąsiadów (osady chłopskie w nowo utworzonych wsiach były oddalone od siebie o kilkadziesiąt minut drogi, która wiodła przez dziewiczy las), osiedleniec był zdany wyłącznie na siebie i swoją rodzinę. Wiele relacji polskich i rusińskich dostarcza dramatycznych opisów zmagań pierwszych kolonistów z naturą. Unicki duchowny, wizytujący Bośnię na początku XX w., opisywał następująco sytuację swoich wiernych: Trzeba było zaczać od zbudowania chaty, żeby było gdzie schować przed deszczem. Wziąt się nasz za piłę a żona za siekierę. Zrąbali parę buków, obciosali i wbili kołki i obłożyli ze wszystkich stron chrustem, obsypali ziemia i już było się gdzie przytulić13. Wspominał również: Po wybudowaniu chaty trzeba było się brać do gospodarki jaka zaczynała się od rąbania dębów i buków. Jak ścięli drzewa to ściagali $w$ jedno miejsce i rozpalali ogień. Teren był tak nierówny, że nieraz brakowało miejsca pod budowe, trzeba było wzmacniać ze wszystkich stron ${ }^{14}$. Warto dodać, że praktycznie nie istniała infrastruktura łącząca poszczególne wioski z innymi ośrodkami, czy to wiejskimi, czy miejskimi. Tym samym utrudniona była jakakolwiek pomoc z zewnątrz, koloniści byli zdani wyłącznie na siebie.

Przez okres 10 lat dzierżawy osadnik zobowiązany był do płacenia sześciu guldenów austriackich na rzecz państwa. Ponadto musiał uiszczać odpowiedni podatek za wszystkie budynki gospodarcze i mieszkalne, które wzniósł na swojej posesji. Wszelkie należności finansowe regulowano na koniec roku kalendarzowego. Przesiedleniec był jednak przez pierwsze trzy lata zwolniony z jakichkolwiek obciążeń płatniczych na rzecz Rządu Krajowego ${ }^{15}$. Umowa osadnicza regulowała także warunki anulowania umowy na wypadek niewywiązania się którejś ze stron ${ }^{16}$. Była to jednak teoria, w praktyce dużą przeszkodą okazała się kwestia własności użytkowanego gruntu po terminie określonym w kontrakcie. Tym samym, pomimo upływu wyznaczonego czasu, tj. 10 lat użytkowania, ziemia nadal nie stawała się własnością dzierżawcy. Problem ten dotykał tak Polaków, jak i Rusinów. Stanowiło to komplikacje, gdyż użytkowanych terenów nie wolno było ani dzielić (np. pomię-

11 Zob. T. J. Lis, Polskie osadnictwo i duchowieństwo w Bośni i Hercegowinie, Toruń 2014, s. 61-64.

12 ABH, ZVS 1905, 134 218/3, s. 7-8.

13 J. Groodskij, Położenie Rusinów w Bośni, Lwów 2003, s. 36 [reprint z 1909 r.].

14 Ibidem, s. 38.

15 F. Kwaśniak, A. Orlovac, Dzieje Polaków w Bośni 1895-1946, Legnica 2013, s. 19.

16 ABH, ZVS 1905, 134 218/3, s. 8. 
dzy dorastające dzieci), ani tym bardziej sprzedawać. Zdarzały się jednak wypadki łączenia działek - ze względu na brak możliwości kontynuowania pracy na roli spowodowanej zaawansowanym wiekiem rolnika lub jego chorobą ${ }^{17}$.

Nie każdy mógł jednak wyjechać do Bośni. Rząd Krajowy stawiał wymagania co do kandydata na osadnika. Musiał on przede wszystkim wykazać się znajomością rolniczego fachu oraz niekaralnością. Ponadto $\mathrm{z}$ rodzimej gminy musiał uzyskać specjalne „świadectwo moralności”, w którym sołtys wystawiał opinię na jego temat ${ }^{18}$. Istniała również odpowiednia poprzeczka finansowa, w wysokości 1200 koron lub 600 złotych, mająca zapobiec przybywaniu do Bośni osób ubogich, niebędących w stanie samodzielnie utrzymać się na początku pobytu na Bałkanach ${ }^{19}$.

Życie w koloniach nie należało do najłatwiejszych. Wszystkie relacje są zgodne, że sytuacja, zwłaszcza na początku, nie była prosta. Brakowało produktów pierwszej potrzeby, po które trzeba było się udać do miasta, często oddalonego o kilkanaście kilometrów od wioski. Wyprawę utrudniał dodatkowo brak odpowiedniej drogi z utwardzoną nawierzchnią. Wątek nieprzejezdnych i grząskich szlaków pojawia się często w źródłach ${ }^{20}$, co świadczy o tym, że był to ogromny problem zarówno dla mieszkańców, jak i osób ich odwiedzających, np. misjonarzy.

Rusini w Bośni i Hercegowinie początkowo byli uważani za Polaków. Przez to byli osiedlani wraz z nimi w mieszanych wioskach. Z czasem jednak konflikty rusińsko-polskie zostały z Galicji przeniesione na bośniacki grunt. W warunkach mocno odbiegających nawet od XIX-wiecznych standardów, tj. bez kurateli policyjnej czy sądowej, których w wioskach po prostu nie było, spory często kończyły się sąsiedzkim samosądem. Z czasem, by uniknąć podobnych problemów, władze postanowiły bardziej rozważnie planować parcelacje gruntów chłopskich. Najprawdopodobniej każda narodowość miała swojego geodetę, który zajmował się rozpisywaniem gruntu. Dla Rusinów i Polaków był to Robert Miączyński, absolwent Politechniki Lwowskiej, który został specjalnie oddelegowany do pracy z kolonistami z Galicji. $Z$ jego formularza osobistego wiadomo, że posługiwał się językiem ukraińskim ${ }^{21}$.

Władze austro-węgierskie przewidziały dla osadników, poza działkami 10-12-hektarowymi, również gotowe plany budynków mieszkalnych. Ze względu na zamożność przesiedleńca przewidziano kilka rodzajów chat ${ }^{22}$. Trudno jednak powiedzieć, jak te plany miały się do rzeczywistości i czy osadnicy przestrzegali wytycznych. Nie wiadomo także, czy groziły jakieś sankcje za niedostosowanie się do nich. Przewidziano też dla nich osobne miejsca na szkołę, kościół i budynki gminy ${ }^{23}$.

17 ABH, ZVS, 1901, 4 32/114, s. 3

18 ABH, ZVS, 1906, 252 218/616.

19 ABH, ZVS, 1901, 4 32/266, s. 3.

20 Bardzo negatywnie na temat infrastruktury pisał bp Adam Stefan Sapieha, który podróżował po Bośni i Hercegowinie w 1896 r. Archiwum Kurii Metropolitalnej w Krakowie, Teki Sapieżyńskie, XXXVI/2, s. 1-2. Por. M. Czermiński, Nad Bosforem, w Bośni i na Krecie, Kraków 1901, s. 72-73.

21 ABH, ZVS, Personalni Dosea, formularz Roberta Miączyńskiego [brak sygnatury].

22 ABH, ZVS, 189626 1/2, s. 2.

23 ABH, ZVS, 1905134 218/3, s. 7. 
Warto zaznaczyć, że koloniści byli w Bośni i Hercegowinie elementem kulturotwórczym. Przybysze z Galicji przywieźli ze sobą nieznane dotąd warzywa i zboża, a także sposoby hodowli czy uprawy roli. Dieta bośniackiego chłopa była bardzo uboga. Żywił się on najczęściej kukurydzą w różnej postaci, cebulą, a także rzepą. Ponadto gustował w mięsie, w zależności od wyznania - wołowina (muzułmanin) lub wieprzowina (prawosławny/katolik). Dopiero osadnicy nauczyli miejscowych uprawy niektórych rodzajów zbóż, przyczyniając się znacznie do podniesienia poziomu rolnictwa na bośniackiej $\mathrm{wsi}^{24}$.

Novum, jakie wprowadzili, dotyczyło również kwestii hodowli rogacizny i nierogacizny, dla której budowali zagrody. Dotychczas lokalni chłopi trzymali zwierzęta w polu bez względu na porę roku. Szczególnie dużo szkody powodowały świnie, chętnie hodowane przez Serbów. Żalił się przytaczany bazylianin Józef Groodskyj, że: $W$ Bośni ani świń, ani bydła, ani koni nikt nie pasie. Zwierzęta $w$ lecie i zimie chodza samopas, [...]. Serbskie świnie sa niebezpieczne, to jakaś inna rasa niż u nas. [...] Jeszcze nie zdarzyło się, żeby serbska świnię wilki zjadły, one sobie chodza swobodnie po lasach gdzie oczy poniosa. Jeśli gospodarstwo nie jest ogrodzone to kłopot wielki i bez przerwy gospodarze musza naprawiać ogrodzenia ${ }^{25}$.

Wyższy poziom kultury rolniczej nie był jedynym elementem zjednywania sobie sympatii miejscowej ludności. Równie istotne, jak nowości przy uprawie zbóż $\mathrm{i}$ hodowli, były także inne praktyczne umiejętności. Ograniczony kontakt $\mathrm{z}$ miastem i tamtejszymi rzemieślnikami spowodował potrzeby wykształcenia własnych fachowców. Z tego powodu niektórzy chłopi decydowali się na „przekwalifikowanie”, przez co wioski zyskały kowali, krawców czy też młynarzy. W efekcie takich działań, jak można łatwo się domyśleć, osadnicy zyskali rychło przewagę nad miejscową ludnością. Czasami doprowadzało to do frustracji miejscowych rolników, gdyż ich pola, nieumiejętnie obrabiane, przynosiły o wiele mniejsze plony niż kolonistów ${ }^{26}$.

Zasadniczo kontakty pomiędzy osadnikami a ludnością miejscową były dobre. Przeszkodą jednak były konflikty rusińsko-polskie. Wcześniej zasygnalizowałem już ten problem przy okazji zakładania niejednolitych etnicznie wiosek. Zaprzestanie osadnictwa mieszanego nie doprowadziło do wygaśnięcia wzajemnych pretensji. Jedną z głośniejszych spraw była kwestia kościoła w mieszanej rusińsko-polskiej wiosce Devetinie ${ }^{27}$. Konflikt dotyczył kościoła, który został wybudowany wspólnymi siłami przez mieszkańców wioski - Rusinów i Polaków. Gdy budowa zbliżała się ku końcowi, pierwsi zażądali

24 ABH, ZVS, 1905134 218/3, s. 8.

25 J. Groodskyj, op. cit., s. 39-40. Na ten sam problem zwracał także uwagę polski misjonarz jezuita Marcin Czermiński, który również pisał, że jednym z powodów zatargów między nowo przybyłymi a sąsiadami były szkody czynione przez trzodę. Por. M. Czermiński, Z podróży po Bośni i Hercegowinie, Kraków 1898, s. 319-320.

26 K. Kwaśniewski, Z badań nad kulturą reemigrantów polskich $z$ Bośni, „Zeszyty Etnograficzne”, T. 1, (1963), s. 87.

27 O jej mieszanym składzie etnicznym poza informacjami znajdującymi się w dokumentach świadczy także niedawno odnowiony cmentarz, gdzie poza nagrobkami polskimi można było spotkać wiele nagrobków rusińskich i serbskich. 
umieszczenia w kościele podobizn słowiańskich świętych, Cyryla i Metodego, drudzy natomiast zakupili już obraz Matki Boskiej Częstochowskiej ${ }^{28}$. O ile relacja rusińska jest jednoznacznie negatywna i całą winę za ten konflikt zrzuca się na Polaków ${ }^{29}$ (więc należy ją traktować $\mathrm{z}$ odpowiednim dystansem), o tyle relacja polskiej zakonnicy nie pozostawia złudzeń, co do winy jej rodaków ${ }^{30}$. Nie chcieli oni, nawet za namową bp. Marijana Markovića, zgodzić się na modernizację kościoła, by mógł służyć i katolikom, i unitom ${ }^{31}$. Odgrażali się także, że usuną siłą unickiego bp. Segedego, którego, według relacji Groodskyjego, chciano nawet zabić (sic!) ${ }^{32}$, a który nie zgodził się na ołtarz niespełniający warunków do pełnienia nabożeństwa w obrządku greckokatolickim.

Konflikt o kościół w Devetinie jest bodaj najbardziej jaskrawym przykładem niesnasek pomiędzy Polakami a Rusinami. Wioska ta nieprzypadkowo posiadała dwóch wójtów, gdyż kilka lat wcześniej, zanim zaczęły się zatargi o kościół, urząd wójta pełnił tam Rusin, którego malwersacje finansowe (co ciekawe, przy budowie cerkwi) i niesprawiedliwa polityka względem polskich sąsiadów doprowadziły przed sąd ${ }^{33}$. Po zakończeniu budowy kościoła konflikt nie ustał, ponieważ, z braku unickiego duchownego, nabożeństwa odprawiał łacinnik, który nie chciał darmo odprawiać mszy dla unitów ${ }^{34}$. O tym, że stosunki narodowe rusińsko-polskie były tam napięte właściwie przez cały czas, przynajmniej do końca I wojny światowej ${ }^{35}$, świadczy sprawozdanie, którego datę określam między 1912 a 1914 r., traktujące przez anonimowego autora o potrzebie sprowadzenia nauczyciela znającego język „ruteński”, a najlepiej będącego Rusinem, gdyż miejscowi unici nie chcą posyłać swoich dzieci do szkoły, gdzie nauczycielem byłby wyłącznie Polak ${ }^{36}$.

Konflikty rusińsko-polskie, do jakich dochodziło w Bośni i Hercegowinie między chłopami, stanowią osobny temat wart zbadania z jeszcze jednego bardzo istotnego powodu. W sporze tym mamy do czynienia właściwie wyłącznie z problemami występującymi w gronie chłopów. Ich status majątkowy był praktycznie identyczny, podobnie jak uprzywilejowanie ze strony władz miejscowych, które, zwłaszcza na początku, nie wykazywały żadnego uprzedzenia w stosunku do Rusinów, o czym świadczy tak liczna emigracja grekokatolików. Przypadek ten pokazuje, że wbrew twierdzeniom dawniejszej marksistowskiej historiografii ${ }^{37}$, konflikty rusińsko-pol-

28 Archiwum Główne Sióstr Felicjanek w Rzymie, Korespondencja siostry Leonardy Odrzywolskiej [dalej: AGSF], 2173-903, s. 71.

29 Zob. J. Groodskyj, op. cit., s. 57-62.

30 AGSF, 2173-903, s. 90.

31 Unici w cerkwiach budują ołtarz oddalony kilka metrów od ścian tak, by można było go obejść w czasie nabożeństwa.

32 J. Groodskyj, op. cit., s. 58.

33 M. Czermiński, Kolonie Polskie w Bośni, Kraków 1903, s. 30.

34 J. Groodskyj, op. cit., s. 57.

35 Niestety nie posiadam informacji na temat stosunków polsko-rusińskich po $1918 \mathrm{r}$.

36 ABH, ZVS [brak daty], 218/12, s. 7.

37 R. Stobiecki, Historia narodowa wobec historii imperialnej. Z dziejów polsko-rosyjskich sporów historiograficznych w XIX i XX wieku, „Kultura i Historia” 20/2011, http://www.kulturaihistoria.umcs. lublin.pl/archives/3018 [dostęp dnia: 31.05.2014]. 
skie w XIX i na początku XX w. nie miały wyłącznie charakteru klasowego, gdzie rusińska/ukraińska klasa chłopska walczyła z polskimi wyzyskiwaczami, ale bardziej miały one podłoże narodowe i religijne, co pokazuje przykład trudnego sąsiedztwa rusińsko-polskiego w Bośni i Hercegowinie. Ponadto Polska inteligencja, o której nieco więcej w dalszej części, wykazywała pozytywny stosunek do chłopów rusińskich, pomagając im m.in. w sprowadzeniu unickich parochów z Galicji, by uniknąć ich konwersji na prawosławie.

Problem konfliktów z Polakami nie był jednak jedynym, jaki sprawiali Rusini władzy austro-węgierskiej. O wiele bardziej groźnym, z punktu widzenia władzy, procesem była sprawa konwersji z religii unickiej na prawosławie. Kwestia była o tyle trudna, że polityka władz bośniackich była skierowana przeciwko prawosławnym Serbom. To m.in. z tego powodu zarządca Bośni, minister Benjamin Kállay, osiedlił katolickich i unickich kolonistów w wioskach rdzennie serbskich, by wewnętrznie rozbić ich jedność i tym samym osłabić ich pozycję w Bośni i Hercegowinie. Chciał w ten sposób powstrzymać destrukcyjne dla władzy w Wiedniu siły, które od wewnątrz i z zewnątrz (Serbia i Czarnogóra) starały się wyrwać Bośnię spod kurateli Franciszka Józefa I ${ }^{38}$.

Wobec tak prowadzonej polityki konwersje na prawosławie były sprawą znaczącą. Unici przechodzili na prawosławie głównie z powodu braku własnej opieki duszpasterskiej. Problem ten był poważny. Do 1902 r. większość Rusinów była zdana na opiekę jednego kapłana, ks. Šegediego. Liczba wiernych rozsianych praktycznie po całej Bośni, a także jego problemy alkoholowe powodowały, że nie był on w stanie zadośćuczynić potrzebom duchowym swoich podopiecznych ${ }^{39}$. Szczególnie że był on pochodzenia węgierskiego, co stwarzało, zwłaszcza na początku, barierę językową.

Tym samym problem konwersji unitów na prawosławie, mimo zapewnień Groodskyjego ${ }^{40}$, istniał i był szeroko dyskutowany. Jednym z pierwszych, który zauważył ten problem i zajął się nim, był o. Marcin Czermiński. W czasie swojej misji do polskich kolonistów w Bośni spotykał również Rusinów, którzy przystępowali do prawosławnej cerkwi ${ }^{41}$. Między jezuitą a przedstawicielami społeczności rusińskiej wywiązała się interesująca dyskusja dotycząca ich przechodzenia do kościoła prawosławnego. Poza kwestiami dogmatycznymi, takimi jak pochodzenie Ducha Świętego, zwracali oni przede wszystkim uwagę na elementy obrządku unickiego, które wyraźnie odróżniają ich od łacinników ${ }^{42}$. Jest to kolejne świadectwo pokazujące, że główną przyczyną przystępowania do kościoła prawosławnego była obawa przed latynizacją, a także polonizacją. Robert Miączyński - geodeta - zapisał, że: Rusini z Galicji zgubili w największej części poczucie przynależności do Polski

38 T. J. Lis, op. cit., s. 62.

39 Archiwum Prowincji Polski Południowej Towarzystwa Jezusowego w Krakowie [dalej: ATJKr], List Franciszka Jakubowskiego do o. Marcina Czermińskiego, 07.10.1910, 272/IV.

40 J. Groodskyj, op. cit., s. 52.

41 M. Czermiński, Z podróży po Bośni..., s. 332-334.

42 Idem, Wspominienia $z$ missyi między Polakami nad Bosforem w Bośni i na Krecie, Kraków 1901, s. 88-90. 
okazywanej w pierwszych latach swego pobytu $z$ bardzo małymi wyjątkami ${ }^{43}$. O tym, iż unici zaczęli zwracać uwagę na swoją odrębność dopiero po jakimś czasie, informuje także Polski slawista Jan Magiera, który twierdzi, że dopiero po przybyciu do Bośni Rusini wyraźnie zaczęli podkreślać swoje pochodzenie ${ }^{44}$. Fakt ten potwierdza również anonimowe sprawozdanie, które znajduje się w Archiwum Bośni i Hercegowiny: [...] przy zakładaniu kolonii podawali się za Polaków, a dopiero po otrzymaniu numeru gruntu przyznawali się do narodowości ruteńskiej ${ }^{45}$. Dzięki temu zapewne łatwiej im było uzyskać zgodę na wyjazd.

Obawa przed wynarodowieniem była więc, jak można przypuszczać, głównym powodem przechodzenia na prawosławie. Proces ten niepokoił także władze. Już w 1903 r. urzędnik nazwiskiem Madurowicz ${ }^{46}$ ostrzegał władze przed zasiedlaniem terenów przez rodziny rusińskie ${ }^{47}$. W dalszej części radził Wysokiemu Krajowemu Rządowi, by ten przybyłych już unitów organizował w możliwie jak największych jednolitych etnicznie skupiskach, gdyż: [...] ludzie Ci znajdują się już od dłuższego czasu w kraju i nie możemy ich tak po prostu się pozbyć. Rozproszyliby się oni po kraju na bardzo małych posiadłościach albo jako kmieci, dzierżawcy ziemscy albo coś podobnego ${ }^{48}$ i potem prawdopodobnie realizowali się jako ortodoksi ${ }^{49}$. Obawy urzędników były uzasadnione.

Władze austro-węgierskie w swoich działaniach politycznych miały niejednoznaczny stosunek do mozaiki narodowej zamieszkującej tereny podległe Habsburgom ${ }^{50}$. Nie inaczej było w wypadku poczynań władz odnośnie do problemu konwersji unitów na prawosławie. Z jednej strony, jak widać, zdawały sobie sprawę $\mathrm{z}$ wagi problemu, $\mathrm{z}$ drugiej jednak nie zgadzały się na szerszą akcję misyjną duchownych unickich. Historycy twierdzą, że odmowa udzielona bp. Julji Drohobyczemu, dotycząca misji 11 ojców bazylianów w 1900 r., a także późniejsza niechęć do utworzenia hierarchii unickiej w Bośni i Hercegowinie, miała swoje korzenie w obawie przed działalnością unijną, jaką kler greckokatolicki mógłby prowadzić w stosunku

43 ABH, ZVS 1905, 134 218/3, s. 9.

44 J. Magiera, Ludność Polska w Bośni, Kraków 1912, s. 4.

$45 \mathrm{ABH}, \mathrm{ZVS}$ [brak daty], 218/12, s. 3.

46 Był to dr Mieczysław Ritter von Jelita Madurowicz lub jego syn Edward Madurowicz. Zob. T. J. Lis, Wkład Polaków w modernizację Bośni i Hercegowiny w okresie austro-węgierskim, „Studia Migracyjne - Przegląd Polonijny", R. 30, z. 4 (2014), s. 120.

47 ABH, ZVS, 1903, 4 45/359, s. 2-6.

48 Autor ma na myśli tzw. komorników. Koloniści, którzy nie byli w stanie samodzielnie się utrzymać, zatrudniali się na służbę u bogatszych właścicieli, którzy za wykonaną pracę płacili im miejscem do spania zwanym „komorą”. Por. AGSF, 18.04.1904, 2173/903, s. 102. A także: J. Magiera, Na Jugu słowiańskim, Kraków 1911, s. 61. Wydaje się, że problem komorników w większej części dotyczył ludności rusińskiej niż polskiej. Por. ABH, ZVS [brak daty], 218/12, s. 6.

49 ABH, ZVS, 1903, 4 45/359, s. 6.

$50 \mathrm{Z}$ jednej strony dopuszczały rozwój niektórych organizacji o charakterze narodowym, jak i umożliwiały świętowanie publiczne ważnych rocznic, z drugiej jednak - zakazywały szerszej agitacji narodowej, zabraniając m.in. tworzenia towarzystw muzycznych o charakterze serbskim czy chorwackim. T. Kraljačić, Kalajev režim u Bosni i Hercegovini, Sarajevo 1987, s. 170-174. 
do Serbów zamieszkujących podległą im prowincję $e^{51}$. Warto bliżej przyjrzeć się opinii chorwackiego historyka Peklića. Władze austro-węgierskie przede wszystkim obawiały się żywiołu słowiańskiego, który mógłby zagrozić stabilizacji Monarchii, w tym celu prowadziły politykę skłócania katolików z prawosławnymi i muzułmanami. Dopóki im się to udawało, widmo zjednoczenia Słowian pod sztandarami jugosłowiańskimi i w dalszej perspektywie utworzenia samodzielnego bytu państwowego na Bałkanach ${ }^{52}$ było daleko. Działalność na rzecz zjednoczenia katolików z prawosławnymi mogłaby jednak mocno zachwiać dotychczasowym układem sił i pchnąć Serbów w ramiona Chorwatów. Strach przed wspólnotą słowiańską, która w najlepszym wypadku domagałaby się trójczłonowej monarchii, a w najgorszym niepodległego jugosłowiańskiego państwa, był więc zdecydowanie większy niż obawy o konwersje kilku tysięcy unitów na rzecz prawosławia. Nie jest to jedyna przyczyna, dla której władze nie zgadzały się na hierarchię unicką. Drugim ważnym powodem był niepokój przed wzmocnieniem abp. Josipa Stadlera, który był gorącym orędownikiem utworzenia tego porządku.

Chorwacki dostojnik swój plan utworzenia hierarchii obwieścił władzom w 1907 roku. Dokument ten był elementem szerszej kampanii Stadlera na rzecz otrzymania autonomii kościoła katolickiego w Bośni i Hercegowinie na takich samych zasadach, na jakich autonomię uzyskali wyznawcy prawosławia dwa lata wcześniej. Koncepcja ta wymaga osobnego omówienia, dlatego ja ograniczę się wyłącznie do części poświęconej planom utworzenia hierarchii unickiej.

Stadler zakładał utworzenie biskupstwa greckokatolickiego w Sarajewie, dodatkowo -powołanie do życia parafii w Banja Luce, Prnjavorze, Zavidovići i Dubravie. Miejscowości te cechowały się stosunkowo liczną diasporą unicką. Biskupem miał zostać Dan Šajatović, natomiast, ze względu na brak odpowiednio przeszkolonych chorwackich duchownych unickich (znających język ukraiński), proboszczów sprowadzono by z Galicji ${ }^{53}$. Ponadto w stolicy kraju planował utworzenie klasztoru bazylianów.

Odpowiedź władz była, jak można się spodziewać, negatywna. Przede wszystkim zwracano uwagę na fakt zawyżenia przez Stadlera liczby grekokatolików w Bośni, a co za tym idzie, podważono jego prośbę dotyczącą powołania tak licznej sieci parafialnej i dodatkowo utworzenia klasztoru w Sarajewie. Zgodzono się jednak na powołanie biskupa pomocniczego greckokatolickiego odpowiedzialnego za unickich mieszkańców Bośni.

Nie tylko władza negatywnie odnosiła się do pomysłu utworzenia hierarchii greckokatolickiej w Bośni i Hercegowinie. Także w łonie samego kościoła katolickiego

51 W 1895 r. w czasie wizyty bp. Drohobyczego w Bośni doszło do konwersji Serbów na grekokatolicyzm. Dopiero stanowcza reakcja Kállaya powstrzymała dalsze działania w tym kierunku. J. Peklić, Život i djelo križevačkoga biskupa Julija Drohobeckog, „Podravina” 5/2004, t. 3, s. 84.

52 Często określano Belgrad jako „Piemont Bałkanów”, który miał zjednoczyć wokół siebie południowych Słowian. D. MacKenzie, Serbia as Piedmont and the Yugoslav Idea, 1804-1914, „East European Quarterly", t. 28, z. 2, (1994), s. 153-182.

53 Z. Grijak, Predstavka episkopata vrhbosanske metropolje iż 1903 godine u svjetlu austrougarske vjerske politike u Bosni i Hercegovini, „Chroatica Christiana Periodica” 62/2008, R. 32, s. 99. 
nie brakowało antagonistów tej koncepcji. Głównym przeciwnikiem Stadlera w tej kwestii i nie tylko był franciszkanin, od 1884 r. biskup Banja Luki. Obawiając się, że nowa hierarchia osłabiłaby jego wpływy w podległych mu parafiach, swój sprzeciw argumentował tym, że wbrew temu, co pisze Stadler, liczba Rusinów nie jest tak duża. Uznał więc, że działalność ks. Szegediego jest wystarczająca dla potrzeb duchowych jego unickich parafian. Ponadto przybycie greckokatolickich duchownych mogłoby zaognić i tak już bardzo napięte stosunki pomiędzy Rusinami i Polakami ${ }^{54}$. Odmowa pomocy Stadlerowi była echem większego konfliktu pomiędzy sarajewskim arcybiskupem a zakonem franciszkanów, z którego wywodził się Marijan Marković. Po odrzuceniu propozycji arcybiskupa Stadlera Rusini musieli czekać jeszcze kilka lat na pewne zmiany.

Sytuacja zmieniła się na korzyść grekokatolików w 1910 roku. Wówczas to bp Andrzej Szeptycki, który wizytował Bośnię parę lat wcześniej, przysłał kilku księży tego obrządku do pracy z rusińskimi wiernymi. Głównym wikarym został dr Józef Żuk, który do pomocy otrzymał kilku duchownych z zakonu bazylianów. Następca Szegediego energicznie zabrał się do powierzonych mu zadań, co, zdaniem Franciszka Jakubowskiego, wróżyło dobre perspektywy na przyszłośćs ${ }^{5}$.

Niestety, nie posiadam zbyt wielu informacji, które mogłyby rzucić nieco światła na tę sprawę. Nie wiadomo, jak doszło do uzyskania zgody władz rządowych w Sarajewie, a przede wszystkim bp. Markovića. Jedynym źródłem, którym dysponuję, są listy Franciszka Jakubowskiego, „Okružnika” obwodu Banja Luka. W jego korespondencji z o. Marcinem Czermińskim pojawia się sporo informacji na temat problemów ludności rusińskiej. W jednym z nich datowanym na październik $1910 \mathrm{r}$. pisał: Udało mi się uregulować stosunki kościelne Rusinów i przeszkodzić dalszemu szerzeniu się szyzmy. W powiecie Prynjavor mamy teraz trzy parafie ruskie z księżmi Rusinami $z$ Galicji ${ }^{56}$. Z powodu braku innych źródeł trudno zweryfikować tę informację. Jeśli jednak Jakubowski był odpowiedzialny za sprowadzenie duchownych greckokatolickich do Bośni, to nie ulega wątpliwości, że sytuacja polityczna musiała być na tyle sprzyjająca, by można było taką akcję przeprowadzić. Rok wcześniej Polak informował o. Czermińskiego, że bp Marković nie chce nawet słyszeć o jakiejkolwiek większej akcji misyjnej greckokatolickich duchownych w granicach swojego dekanatu ${ }^{57}$, by już w rok później zgodzić się na wikariusza generalnego i kilku pomocników. Z pewnością musiało wydarzyć się coś, co spowodowało zmianę stanowiska banjaluckiego biskupa. Być może były to naciski ze strony władz, trudno spodziewać się przecież, by to Jakubowski wpłynął swoją osobą na stanowisko bp. Markovića, tym bardziej że ten również nie przepadał za Polakami. Poza tym, jeśli polski urzędnik miałby takie możliwości, dlaczego nie sprowadziłby na początku księży katolickich z Galicji, by w pierwszej kolejności zadośćuczynić prośbom swoich

54 Ibidem, s. 97.

55 ATJKr, List Franciszka Jakubowskiego, 25.11.1910, 272/IV.

56 ATJKr, List Franciszka Jakubowskiego, 31.10.1910, 272/IV.

57 ATJKr, List Franciszka Jakubowskiego, 07.10.1909, 727/IV. 
rodaków? Z pewnością więc sprowadzenie ks. dr. Józefa Żuka i podwładnych mu ojców bazylianów stało się możliwe za sprawą odpowiedniej atmosfery politycznej. Być może, dzięki połączeniu sił Stadlera, Szeptyckiego i Jakubowskiego udało się przekonać władze, że wzrastająca liczba Rusinów stanowi większe zagrożenie niż obawy przed działalnością unijną duchownych greckokatolickich. Tym bardziej że sami Rusini bardzo mocno zabiegali o pomoc władz krajowych ${ }^{58}$. Teza ta wydaje się o tyle prawdopodobna, że w 1900 r., kiedy po raz pierwszy powstał pomysł sprowadzenia ojców bazylianów, Bośnią i Hercegowiną rządził Benjamin Kállay, Węgier, który z wielką pasją zwalczał wszystkie idee jugosłowiańskie tlące się na Bałkanach. W 1910 r. stanowisko to piastował już bardziej liberalny Istvan Burian, który miał zupełnie inne priorytety względem Bośni. Ponadto kraj ten został już dwa lata wcześniej anektowany i nawet doczekał się konstytucji. Sytuacja wydawała się więc na tyle stabilna, że kilku księży unickich nie stanowiło żadnego zagrożenia dla austro-węgierskich interesów na Bałkanach.

Wydaje się, że aktywność bp. Szeptyckiego, poparta przez władze świeckie (Jakubowski) i duchowne (Stadler ${ }^{59}$ ) w Bośni, trafiła wreszcie na dobrą polityczną atmosferę, dzięki czemu stało się możliwe działanie na rzecz poprawy losu wiernych. Trzeba zaznaczyć, że starał się on objąć swoją opieką grekokatolików na Bałkanach, mimo ograniczonych możliwości. Z własnych funduszy wykupił dla nich kilkusethektarowy teren w pobliżu miejscowości Kamienica, który w części oddał im w użytkowanie ${ }^{60}$, a w części przeznaczył na klasztor ${ }^{61}$. Kontrolował należące doń tereny poprzez swoich podwładnych, których od czasu do czasu wysyłał z misją do Bośni. W memoriale skierowanym do bp. Sapiehy Polacy wspominają m.in. właśnie o skutecznych działaniach na rzecz swoich wiernych, jakie podejmował bp Szeptycki: Zajął się nimi [Rusinami - T. J. Lis] i zaopiekowat jeszcze przed laty kilkunastu energicznie ze skutkiem $k$. A. Szeptycki, arcybiskup ruski ze Lwowa. Sprowadzit im zakonników Studyłów z kilku księżmi świeckimi, dopomógł pieniężnie do budowy cerkwi, nawet ustanowił jednego wizytatora nad wszystkimi rusinami w Bośni ${ }^{62}$. Bp Szeptycki zdawał sobie sprawę z niebezpieczeństwa prawosławnego, z którym się zmagał także w Galicji ${ }^{63}$, dlatego też jego działania były tak zdecydowane. Wiedział, że cała emigracja rusińska do Bośni zostanie utracona na rzecz prawosławia, jeśli nie rozwiąże tego problemu. Stąd jego pełne zaangażowanie dla tej sprawy. O ile kwestia opieki duszpasterskiej została rozstrzygnięta ${ }^{64}$, o tyle inne problemy, takie jak brak własnej edukacji czy konflikty z Polakami, nadal pozostały nierozwiązane.

58 ABH, ZVS, 1906, 103 2/5, s. 1.

59 Josip Stadler, podobnie jak Andrzej Szeptycki, był wielkim orędownikiem kultu Najsłodszego Serca Jezusowego, co z pewnością miało wpływ na poparcie z jego strony grekokatolików w Bośni.

60 J. Groodskyj, op. cit., s. 45-47.

61 ABH, ZVS, 1903, 4 45/359, s. 6.

62 AKMK, TS. XX/18, s. 19.

63 W. Osadczy, Święta Ruś, Lublin 2007, s. 570.

64 Sytuacja została opanowana wyłącznie do wybuchu I wojny światowej. W 1927 r. w raportach polskich duchownych czytamy o falowych konwersjach ludności greckokatolickiej na prawosławie. 
Warto zasygnalizować także, że emigracja Rusinów dotyczyła nie tylko rolników, ale również kadry urzędniczej. Austro-Węgry, by podnieść gospodarczo Bośnię i Hercegowinę, musiały skorzystać z pomocy wielu urzędników, z których lwią część stanowili przybysze z Galicji. W większości byli to Polacy, wśród nich jednak można spotkać także Rusinów, którzy szukając szans na rozwój swoich karier, decydowali się porzucić dotychczasowe miejsce zamieszkania i przenieść się na Bałkany. Byli to lekarze, prawnicy, urzędnicy. Trudno pokusić się o jakiekolwiek liczby, pisząc o rusińskich absolwentach galicyjskich szkół wyższych poszukujących swojej szansy na szybką karierę w administracji austro-węgierskiej w Bośni i Hercegowinie. Z kwerendy teczek urzędniczych, jakie znajdują się w Archiwum Bośni i Hercegowiny, które jednak nie są kompletne, wynika że Rusinów w administracji austro-węgierskiej było nieco mniej niż Polaków. Zajmowali oni różne stanowiska, od lekarzy, poprzez pracowników sądów i urzędów, aż po nauczycieli w szkołach ${ }^{65}$. Urzędnicy deklarujący się jako Rusini byli najczęściej greko-katoliccy. W trakcie kwerendy natrafiłem jednak na kilka przypadków osób, które kilkukrotnie w różnych odstępach czasu zadeklarowały się jako Rusini, a w rubryce religia wpisały „rzymski-katolik”66.

Konkludując, kolonizacja rusińska w Bośni i Hercegowinie stanowi jedno z najciekawszych wciąż niezbadanych zagadnień w historii emigracji galicyjskiej z II połowy XIX wieku. Grekokatoliccy mieszkańcy tych ziem, podobnie jak ich polscy sąsiedzi, zmuszeni wszechobecnym niedostatkiem, decydowali się porzucić dotychczasowy nędzny żywot i spróbować swojego szczęścia „za Bałkanem”. Wielu z nich udało się, osiągnęli sukces i zdecydowanie poprawili swój los. Część z nich, narażona na trudy codzienności, nie poradziła sobie i popadła w jeszcze większą biedę niż ta, przed którą uciekali na południe. Wbrew opowieściom o fantastycznych warunkach, zamiast ziemi obiecanej zderzali się z trudną i brutalną rzeczywistością, która narażała ich na śmierć indywidualnie, ale także jako całej grupy. By bronić się przed wynarodowieniem, posuwali się nawet do konwersji na prawosławie. Dzięki opiece, jaką objął osadników bp Andrzej Szeptycki, tragiczna sytuacja z początku XX w. uległa w późniejszych latach niewielkiej poprawie. Paradoksalnie trudniej było im się porozumieć z „dawnymi” sąsiadami Polakami niż Serbami czy muzułmańskimi Bośniakami. Spory te stały się zarzewiem waśni pomiędzy dwoma pokrewnymi narodami, które konflikty z Galicji przenosiły na Bałkany.

W swoim artykule skupiłem się na sporze, jaki występował w wielonarodowej wiosce Devetinie. Niemniej jednak dochodziło do większej liczby podobnych ekscesów, co może stanowić interesujący materiał badawczy nie tylko dla historyków, ale także etnologów i kulturoznawców. Mam nadzieję, że kolonizacja rusińska w Bośni i Hercegowinie doczeka się odpowiednio wnikliwego studium, które

K. Kwaśniak, Starania Polskiego Duchowieństwa o poprawę życia duchowego Polaków w Bośni w latach 1920-1930, „Perspectiva” 1/2010, s. 309.

65 W 1910 r. w Bośni i Hercegowinie na ok. 9 tys. urzędników ponad tysiąc było Polakami. ABH, $1905,134218 / 3$.

$66 \mathrm{ABH}$, Personalni Dosjea, formularz osobowy Wiktor Iwasiuk. 
przybliży nam ten jakże interesujący fragment historii zupełnie niezbadany przez naszą historiografię.

\section{TABELA nr 1}

Liczba ludności grekokatolickiej w koloniach według spisu z 1910 r. ${ }^{67}$

\begin{tabular}{|c|c|c|}
\hline Lp. & Kolonia & $\begin{array}{l}\text { Liczba } \\
\text { ludności }\end{array}$ \\
\hline 1 & Opsječko & 110 \\
\hline 2 & Ivanjska & 69 \\
\hline 3 & Jablan & 36 \\
\hline 4 & Donji Bakinci & 33 \\
\hline 5 & Gornji Bakinci & 12 \\
\hline 6 & Bošković & 30 \\
\hline 7 & Glamočani & 11 \\
\hline 8 & Rudofstal & 13 \\
\hline 9 & Bukovac & 50 \\
\hline 10 & Cerovljani & 163 \\
\hline 11 & Bukvik & 57 \\
\hline 12 & Dombrava & 70 \\
\hline 13 & Božinci katolicki & 25 \\
\hline 14 & Derventa $^{68}$ & 58 \\
\hline 15 & Kalenderovci srpski & 43 \\
\hline 16 & Kovačevci & 25 \\
\hline 17 & Lužani Šemsibegovi & 12 \\
\hline 18 & Tetima & 19 \\
\hline 19 & Bosanski Brod & 16 \\
\hline 20 & Krivaja & 18 \\
\hline 21 & Marićka & 109 \\
\hline 22 & Miljakovci & 29 \\
\hline 23 & Prijedor & 27 \\
\hline 24 & Kozarac & 253 \\
\hline 25 & Babanovci muslimanski & 171 \\
\hline 26 & Brezik & 59 \\
\hline 27 & Devetina & 568 \\
\hline 28 & Gajevi & 286 \\
\hline 29 & Ratkovac & 49 \\
\hline 30 & Glogovac & 15 \\
\hline 31 & Gumjera & 69 \\
\hline 32 & Hrvaćan & 302 \\
\hline 33 & Kamenica & 245 \\
\hline 34 & Karači & 66 \\
\hline 35 & Kličkovo brdo & 19 \\
\hline
\end{tabular}

67 Tabela powstała w oparciu o badania A. Busuladžića, op. cit., s. 176-178, i spis ludności przeprowadzony w 1910 r. Die Ergebnisse der Volkszahlung in Bosnien und der Herzegovina, Sarajevo 1912. Obejmuje ona jednak wyłącznie Rusinów osiedlanych w ramach kolonizacji rządowej w latach 1894-1910 w obwodzie Banja Luki, nie ma w nich natomiast liczby Rusinów zamieszkałych w innych częściach Bośni i Hercegowiny.

68 Pogrubioną czcionką zaznaczono miasta. 


\begin{tabular}{|l|l|r|}
\hline Lp. & Kolonia & $\begin{array}{l}\text { Liczba } \\
\text { ludności }\end{array}$ \\
\hline 36 & Konjuhovci & 142 \\
\hline 37 & Lepenica & 57 \\
\hline 38 & Lišnja & 26 \\
\hline 39 & Lišnja - Mujinci & 465 \\
\hline 40 & Lužani & 107 \\
\hline 41 & Mravica srpska & 67 \\
\hline 42 & Mravica turska & 24 \\
\hline 43 & Nova Dubrava & 560 \\
\hline 44 & Prnjavor & 92 \\
\hline 45 & okolica Prnjavora & 164 \\
\hline 46 & Rakovac & 117 \\
\hline 47 & Rasovac & 162 \\
\hline 48 & Selište & 36 \\
\hline 49 & Sitnež Srpski & 13 \\
\hline 50 & Srđević & 66 \\
\hline 51 & Stara Dubrava & 490 \\
\hline 52 & Vučjak Jasici & 58 \\
\hline 53 & Gornji Zavidović & 223 \\
\hline
\end{tabular}

Ruthenian settlement in Bosnia and Herzegovina in the late 19th and early 20th century

The Ruthenian immigration to Bosnia and Herzegovina in the late $19^{\text {th }}$ and early $20^{\text {th }}$ century was one of the largest internal migrations within the Austro-Hungarian Empire. Since 1893, when the Common Minister of Finances Benjamin Kállay announced a state-supervised resettlement operation, over eight thousand Ruthenians relocated to the Balkans.

The Ruthenians moved to Bosnia and Herzegovina along with Poles, with whom they formed ethnically mixed villages. Unfortunately, the mutual antagonisms between Roman Catholics and Greek Catholics from back in Galicia resurfaced near the southern borders of the Empire. This difficult coexistence shows that the conflicts between the Poles and the Ruthenians were motivated not only by social class differences, as historiography used to claim in the past, but by religious and national issues as well.

The aspect of religion, as well as the Ruthenians' sense of national identity on foreign ground, constitutes the main subject of this article. The work aims at presenting a topic so far unknown to our historiography, namely the settlement of Ukrainian Greek Catholics in Bosnia and Herzegovina. It describes the history of the immigration of Greek Catholic peasantry, but also presents the Polish-Ruthenian villages around Banja Luka, which accumulated, like a lens, all the antagonisms between those nationalities in the late $19^{\text {th }}$ and early $20^{\text {th }}$ century.

This article presents, in chronological order, the most important events related to the resettlement, from its beginnings until the end of WWI. The primary sources include documents from Polish and Bosnian archives, almost completely unstudied by our historians. This article is intended as a contribution, which does not aim at presenting the issue exhaustively, but rather is to serve as inspiration for further studies on this subject. 


\section{Русинская колонизация в Боснии и Герцеговине на рубеже XIX и XX вB.}

Русинская колонизация в Боснии и Герцеговине на рубеже XIX и XX вв. была одной из больших внутренних миграций в Австро-Венгерской монархии. Начиная с 1893г., когда общеимперский министр финансов Беньямин Каллаи, решил провести, контролируемую государством, колонизаторскую акцию, на Балканы переселилось свыше 8 тыс. русинов. В Боснию и Герцеговину они направлялись вместе с поляками, с которыми затем создавали национально смешанные села. К сожалению, взаимные антагонизмы между католиками и униатами перенеслись с территории Галиции на южные рубежи Монархии. Трудное соседство показывает, что польско-русинские конфликты не имели исключительно классового характера, как обычно было принято считать в более старой историографии, но также религиозный и национальный.

Религиозный вопрос, а также чувство собственной национальной идентичности среди русинов на чужой боснийско-герцеговинской земле, являются главным сюжетом моей статьи. Эта работа имеет целью представить доселе неизвестный в нашей историографии сюжет, каким являлась колонизация галицкими греко-католиками в Боснии и Герцеговине. Она показывает историю эмиграции униатских крестьянства, но и представляет русинско-польские деревни в окрестностях Банья-Луки, в которых сосредоточились, словно в линзе, все антагонизмы между этими народами на рубеже XIX и XX вв.

Статья в хронологическом порядке демонстрирует самые важные события, касающиеся колонизации - с ее начала в 90-х гг 19 в. по окончание Первой мировой войны. Источниковую базу образуют документы из польских и боснийских архивов, последние почти совсем не изучены нашими историками. Работа играет роль дополнительного материала, который не имеет целью исчерпание темы, а лишь презентацию направления и исторической основы, которая может служить указанием для дальнейших исследований по этому вопросу.

Перевод Агнешка Поспишьль

\section{Bibliografia}

Baczkowski K., Żołnierze narodowości polskiej w podboju i okupacji Bośni i Hercegowiny przez Austro-Węgry (1878-1914), „Zeszyty Naukowe Uniwersytetu Jagiellońskiego. Prace Historyczne 2000", z. 127, s. 107-120.

Busuladžić A., Pojava grkokatoličkog stanovništva u Bosni i Hercegovini, „Izvorni Znanstveni Članak" 1/2003, t. 35, s. 173-188.

Ciuruś E., Dobosiewicz Z., Rómmel W., Polonia w Ameryce Łacińskiej, Lublin 1977.

Czermiński M., Kolonie Polskie w Bośni, Kraków 1903.

Czermiński M., Nad Bosforem, w Bośni i na Krecie, Kraków 1901, s. 72-73.

Czermiński M., Wspominienia $z$ missyi między Polakami nad Bosforem w Bośni i na Krecie, Kraków 1901.

Czermiński M., Z podróży po Bośni i Hercegowinie, Kraków 1898, s. 319-320.

Die Ergebnisse der Volkszahlung in Bosnien und der Herzegovina, Sarajevo 1912.

Glavni rezultati popisa žiteljstva u Bosni i Hercegovini od aprila 1895, Sarajevo 1896.

Grijak Z., Predstavka episkopata vrhbosanske metropolje iż 1903 godine u svjetlu austrougarske vjerske politike u Bosni i Hercegovini, „Chroatica Christiana Periodica” 62/2008, R. 32, s. 77-108.

Groodskyj J., Położenie Rusinów w Bośni, Lwów 2003 [reprint z 1909 r.].

Isaac W., Znaniecki F., Chłop polski w Europie i Ameryce, Warszawa 1976. 
K. Kwaśniak, Starania Polskiego Duchowieństwa o poprawę życia duchowego Polaków w Bośni w latach 1920-1930, „Perspectiva” 1/2010, s. 304-315.

K. Kwaśniewski, Z badań nad kulturą reemigrantów polskich z Bośni, „Zeszyty Etnograficzne”, t. 1 (1963), s. 80-104.

Kasumanović A., Modaliteti eksterne kolonizacije u Bosni 1890-1914: Case Study za njemačke erarne kolonije, „Prilozi” 38/2009, s. 81-120.

Kozaczka M., Wychodźstwo zarobkowe z Galicji do Ameryki (do 1914 r.), [w:] Chłopi. Naród. Kultura. Chłopi a państwo, red. W. Bonusiak, Rzeszów 1997, s. 189-199.

Kraljačić T., Kalajev režim u Bosni i Hercegovini, Sarajevo 1987.

Kula M., Polonia brazylijska, Warszawa 1981.

Kwaśniak F., Orlovac A., Dzieje Polaków w Bośni 1895-1946, Legnica 2013.

Lis T. J., Polskie osadnictwo i duchowieństwo w Bośni i Hercegowinie, Toruń 2014.

Lis T. J., Wkład Polaków w modernizację Bośni i Hercegowiny w okresie austro-wegierskim, „Studia Migracyjne - Przegląd Polonijny”, R. 30, z. 4 (2014), s. 109-124.

Magiera J., Ludność Polska w Bośni, Kraków 1912.

Magiera J., Na Jugu słowiańskim, Kraków 1911.

Mazanek J., Kraj a emigracja galicyjska, Warszawa 2006.

MacKenzie D., Serbia as Piedmont and the Yugoslav Idea, 1804-1914, „East European Quarterly”, t. 28 , z. 2, (1994), s. 153-182.

Osadczy W., Święta Ruś, Lublin 2007.

Peklić J., Život i djelo križevačkoga biskupa Julija Drohobeckog, „Podravina” 5/2004, t. 3, s. 71-88.

Rezultati popisa žiteljstva u Bosni i Hercegovini u 1910, Sarajevo 1912.

Stobiecki R., Historia narodowa wobec historii imperialnej. Z dziejów polsko-rosyjskich sporów historiograficznych w XIX i XX wieku, „Kultura i Historia” 20/2011, http://www.kulturaihistoria.umcs.lublin.pl/archives/3018 [dostęp dnia: 31.05.2014].

Szczepanowski S., Nędza Galicyjska w cyfrach i program energicznego rozwoju gospodarstwa krajowego, Lwów 1888.

Mgr Tomasz Jacek Lis - doktorant na Wydziale Nauk Historycznych i Archiwistyki Uniwersytetu Mikołaja Kopernika w Toruniu. W swoich badaniach zajmuje się głównie historią Bośni i Hercegowiny w okresie panowania austro-wegierskiego, a także Chorwacji w XIX i na początku XX wieku. Stypendysta Uniwersytetu w Sarajewie w 2012 r. na wydziale Nauk Politycznych. Autor kilku publikacji naukowych dotyczących historii diaspory polskiej w Bośni i Hercegowinie. (tomlis88@gmail.com) 